Marek Jasinski

Niepaństwowa Wyższa Szkoła Pedagogiczna w Białymstoku

\title{
The Psychological Difficulties of Adapting to the Aging Process
}

This article is based on clinical observations and will discuss the psychological difficulties of adapting to old age from a psychodynamic perspective. To this end, the first part of this article discusses the normalcy of the aging process. Then, this article will analyze a variety of psychological variables that either disturb or accompany this process such as personality changes, body image, personal and professional fulfillment, satisfaction in relationships, self-esteem, acceptance of changes, and many more. The role of intimacy in old age will be discussed in a separate section, since this is an important element that has a significant impact on an individual's ability to adjust to the aging process. Among other things, this article also considers such issues as resolving basic intrapsychic conflicts, the ability to draw from one's inner strength and appeal to the constructive part of oneself, mourning various types of loss, establishing a realistic understanding of one's self in relation to one's ideal image of oneself, achieving inner harmony, etc. A cognitive approach will be used to present fundamental references to this topic.

Key words: old age, psychoanalysis, cognitive-behavioral therapy, personality changes.

\section{Introduction}

The aging process is a natural phase of development that is subject to certain psychophysiological principles. Although the aging process is unique to each individual and depends on specific human predispositions, how a person experiences this 
process and adapts to it depends on numerous personality and social variables. A person's ability to successfully integrate his or her personality and pass through the aging process depends on how successfully he or she passed through earlier developmental stages. Not only must the elderly deal with internal conflicts, but social attitudes toward the elderly are unfavorable, even to the point that they experience outright discrimination. In our society, the elderly are marginalized, and their knowledge, wisdom about life, and maturity are often neglected. Individuals avoid the elderly so as not to have to witness the transitory nature of life, mortality, their infirmity, and their dependence on others. People also often fear close contact with the elderly because it forces them to confront their subconscious fears, existential problems, and disillusionment in the face of their well-built images of themselves. Avoided and spurned, the elderly are often filled with a deep sense of loneliness and social isolation. These are some of the more important reasons why it is difficult for the elderly to adapt to old age.

\section{Aging is Normal}

Aging is a natural, long, and psycho-physiologically process that involves irreversible biological, psychological, and social changes. An unequivocal definition of old age does not exist. However, from a psychoanalytic point of view, old age begins when a person realizes that he or she will not live forever. ${ }^{1}$ The aging process is smooth for healthy individuals. During this process, the body and its endocrine and organ systems begin to slow and become unbalanced. In turn, the body's composition and structural elements (tissues and organs) begin to noticeably change and deteriorate. However, since the aging process takes place gradually, a person is usually able to adapt to these changes. Both social and psychological factors greatly determine how well people age. While the ability to maintain good psychophysical condition of the body or prolonging "youth" may be linked to a person's socioeconomic status and lifestyle, a person's quality of life during old age is ultimately determined by psychological factors, particularly a person's approach and attitude toward old age as well as other psychosocial variables that will be discussed below.

A. Przewłocka-Alves, "Psychologia starości w ujęciu psychoanalitycznym i perspektywy psychoterapeutycznej," Theologica Wratislaviensia 10 (2015). 
According to WHO, late adulthood is made up of three stages: 1) early age, meaning 65-74 years of age, 2) late old age, meaning 75-89 years of age, and 3 ) longevity, meaning over 90 years of age. The rate at which people age differs according to biological, clinical, and social factors. ${ }^{2}$ Aging can occur in three ways: 1) successfully, meaning a low likelihood of illness and stability, high physical and mental fitness, and an active lifestyle; 2 ) normally, meaning without pathologies, but with an increased risk of disease; and 3) pathologically, meaning the occurrence of several diseases simultaneously that present with different symptoms and require prolonged periods of rehabilitation. ${ }^{3}$ The way in which a person ages depends not only on biological, genetic, and psychological factors, but also on a person's personality and how he or she lived his or her life.

\section{The Psychosocial Determinants of Adapting to the Aging Process}

Genetic and biological factors are at the center of the aging process. But which of these fully reveals or dominates how a person function depends on many psychological, social, and interpersonal factors, a few of which are presented below.

\section{The Experience of Aging and Balancing One's Life}

The way that individuals value old age is important. Perceiving old age only as a time to prepare to depart from life makes a person less motivated to do things, weakens volition, leads to feelings of resignation, and can cause chronic depression. A positive balance in life makes it possible for individuals to experience old age as a time of harmony and relative mental stability. If individuals experience a sense of fulfillment from the significant roles that they play in their lives, then they will have a positive outlook on aging. However, if individuals are very frustrated, then they can become embittered, irritated, and reluctant to enter into new relationships with others.

Za: A. Nowicka,Wybrane problemy osób starszych”, Impuls, 2010

Zawadzka, D., M. Stalmach: Psychological problems in elderly people. Part I. Major challenges and difficulties. Hygeia Public Health 2015, 50(2): 298-304 


\section{Developmental Tasks}

Treating aging as another chapter in life and as a challenge in which one can realize specific tasks and fulfill specific needs is essential to remaining positively motivated in old age. By establishing plans and goals for old age, individuals are more likely to be active in working toward achieving these plans and goals. In turn, this pursuit gives their life meaning, even when their psychophysical abilities are limited. Yet, it is often difficult for people to have this attitude toward old age because they are filled with the sense that time is running out. In other words, by the time they have reached old age, individuals realize that there is relatively little time left to live, and the prospect of impending death discourages them from planning for the future. On the other hand, for others, their sense that there is only a limited amount of time left motivates them to live life more intensely and satisfy needs that have been heretofore neglected or ignored. In this sense, the elderly might find themselves taking one of two approaches to life: 1) very active, which at times can resemble maniacal behavior as they try to "catch up" on everything that they have missed out on in life by overenthusiastically striving to meet their needs beyond reason and seeking satisfaction in the "world" and "people" in order not to miss out on anything, or 2) withdrawn, which manifests itself when people neglect their own essential needs and become discouraged and depressive because they are convinced that everything good has already happened, that nothing good will happen anymore, that it is no longer worthwhile to engage in life since the conditions of life are worse and death is imminent. These are two extreme approaches to old age, and often individuals oscillate between the two approaches to greater or lesser degrees.

In his work, R. J. Havighurst has identified the most important developmental tasks to help the elderly flourish in late adulthood as well as the conditions necessary to fulfill these tasks. First and foremost, he recommends that the elderly adapt their diminishing physical strength and worsening health. It is important for the elderly to accept the changing and often painful quality of their lives, including their increasing sense of limitation and a deepening sense of loss. Other areas to which the elderly need to adapt are retirement and mourning after the loss of loved ones. To this end, therapists suggest that the elderly participate in support groups where they can confront 
and work through their experiences among others who have or are experiencing similar things. ${ }^{4}$

\section{Adequate Self-Assessment}

When individuals base their self-esteem on their psychophysical fitness and physical attractiveness, they will often become disillusioned and have disturbed self-image as they age. The Anthropology natural changes in body image and psychophysical functioning that occur with old age force individuals to adjust how they perceive their own abilities, come to terms with a sense of loss, and surrender their invincible self-image. The more individuals are narcissistically occupied with their external attractiveness, the more affected they are by the changes that occur with old age-changes cannot be reversed or avoided regardless of how advanced plastic surgery or psychological techniques have become. Individuals do resist and attempt to negate these changes by trying to maintain a viable "immortal" self-image. For example, individuals attempt to take on particular personas and change their outward appearance in order to keep other people interested in them, give themselves a sense that time is standing still, and that it is still possible to do everything. Accepting (and not resisting) these inevitable changes, however, is one of the most important ways to adapt. Self-esteem based on non-social values such as wisdom, a positive attitude toward reality, etc. allow the elderly to more harmoniously reconcile themselves to their loss of certain cognitive, psychological, or philosophical abilities.

Throughout old age, unresolved intrapsychic conflicts are exacerbated, defense mechanisms are significantly weakened, and the self-image that an individual has created for himself over years must confront reality. Facing the "truth" about oneself can be either devastating, if a person's self-worth is based on unrealistic expectations, or constructive, if a person's self-image is stable and harmonious.

$4 \quad$ R. J. Havighurst, "Zadania rozwojowe kolejnych okresów życia i warunki wypełniania,” Encyklopedia Pedagogiczna (Warsaw: Fundacja Innowacja, 1997), 952-953. 


\section{The Experience of Grief and the Acceptance of Loss}

During old age, individuals often experience continual mourning due not only to the loss of loved ones, but also to the loss of things that made life meaningful and motivated them to act, such as work and other external sources of gratification. Internally, the elderly also mourn the loss of their own self-image as well as their sense that everything is possible and that life lasts forever. The way in which individuals accept reality determines their quality of life during old age and can prevent them from living in denial by maintain an unrealistic self-image. Successfully adapting to old age, therefore, requires individuals to continually recognize the aging process for what it is and accept all of the limitations that come with it. In the process of adapting to change, a behavioral-cognitive outlook on life that considers old age not as a stage in life where people become more limited in ability and impoverished in experience, but rather as a stage in life that presents opportunities that opens individuals to new, previously inaccessible and unattainable experiences is helpful.

During old age, the psychological defense mechanisms by which individuals uphold unrealistic images of themselves become weakened due to their inability to rationalize or negate their very real and changing experiences. These experiences are so dominant and suggestive that they cannot be "deceived" by defensive psychological manipulation. Gradually losing one's psychophysical ability, reconciling with the impossibility of realizing previous intentions or goals, and losing one's omnipotent self-image is a very difficult process; and, the more individuals build their self-esteem on narcissistic mechanisms, the more difficult this process becomes. However, if individuals can successfully adapt to these changes, then they will be able to embrace a realistic self-image and enjoy new experiences.

\section{Relationship Arrangements}

As individuals' cognitive abilities and physical health decline during old age, they become more dependent on others and their environment. This dependence occurs out of necessity and circumstances and not because the elderly deliberately want or 
will it. Individuals who are highly "self-sufficient" and have based their self-esteem on their narcissistic sense of independence often find it difficult to accept their "forced" dependence on others. Consequently, as a means to bolster their narcissistic defense, they might not accept reality for what it is and, therefore, refuse seek help from others. As a result, this weakens the power of their ego and makes it difficult for them to adapt to the aging process. Anthropology In turn, inadequately reinforcing their sense of independence can expose them to destructive consequences and inhibit them from properly responding to difficult situations. By maintaining a consistent sense of self-sufficiency, aging people attempt to deny the fact that their psychophysical abilities are becoming limited, that they will die, and that they are unable to meet their own specific needs. When individuals want to do more than they can, they may feel like a failure and, consequently, depressed.

Relationship arrangements play an important role in how individuals react to their worsening psychophysical condition and in their denial of the fact that they now need to depend on others. Specifically, the way a partner reacts to the fact that the other person is aging can either help or aggravate the aging process. For example, sometimes the partner does not want to recognize that the aging individual is becoming physically and mentally weaker. Subsequently, the partner tries to artificially strengthen the aging person's "omnipotent" tendencies. This can occur in relationships where the partner bases his own strength on the illusory strength of the aging individual. When this happens, the partner is unwilling to accept anything that would suggest that the aging individual is psychologically impotent. In turn, the partner who literally forces the aging individual to confront the transitory nature of his life and his increasing cognitive impairment and emphasizes the aging partner's dependence on him, can make it difficult for the aging person to adapt to the aging process. In turn, the aging partner's frustration will be manifested in depressive or aggressive reactions. This situation can occur when the aging partner's psychophysical inability triggers negative feelings in the other because the partner has been forced to have to abandon his or her own wants and needs in order to care for the aging person. The partner's negative emotions might 
then come to the forefront as the partner experiences how the relationship has become overwhelming and how he or she is no longer fully gratified by the aging person and the relationship.

\section{Resolving Underlying Interpsychic Conflicts}

In each stage of life, individuals must deal with intrapsychic conflicts. On the one hand, these conflicts can weaken the ego, and, on the other hand, they can mobilize a person's defense mechanisms. Most often these conflicts arise when contradictory aspirations, an inability to accept one's own ambivalence, difficulty in making decisions, and many other things collide. While old age brings to the forefront unresolved internal conflicts, it also entails new conflicts that are particular to this stage in life. These conflicts arise from the discrepancy between individuals' needs and their ability to fulfill these needs. Intrapsychic conflicts manifest the dynamics of life during old age; therefore, many elderly desire to maintain these conflicts within themselves or to allow new areas of conflicts into their lives. Such individuals, who want to ensure that their lives are dynamic, consciously or unconsciously provoke conflicts or deliberately strive to keep current conflicts alive. For the majority of people, however, old age means that their emotions calm down and previous dilemmas, ambivalences, and discrepancies will subside. Often people who process things deeply on a psychological level become more psychologically and emotionally even-tempered, kinder, and more forgiving towards other people or situations. Likewise, these psychological occurrences weaken the libido, further impair cognitive function, slow the metabolism, and intensify the central nervous system's inhibitory processes.

\section{Sexuality During Old Age}

Sexual satisfaction, connecting with another person, and the fulfillment of important psychological needs are important elements of psychological well-being at every stage of adult human life. This is so for old age as well, although the ways of expressing or experiencing intimacy become significantly reduced due to psychosexual inefficiency. However, even when persons are sexually abstinent, they can express intimacy through a wide range of experiences, feelings, and behaviors that do not involve sexual intercourse, such as attachment, sense of security, deep 
understanding, and unity. And elderly person's sexuality should be considered on three basic levels: biological, psychological, and social. ${ }^{5}$

During old age, there are many biological factors that interfere with a person's psychophysical efficiency and ability to perform sexually, including: reduced psychomotor fitness, age-specific changes in the appearance of both partners, specific diseases, medications, etc. However, as stated previously, sexual satisfaction does not have to be directly linked to sexual intercourse. Rather, elderly couples can experience an emotional connection with each other based on past experiences that they share, bonding, and showing each other their deep attachment and affection.

Psychologically, elderly couples can find that aging affects their selfesteem due to one partner's lack of acceptance of the changes that take place in the other partner during the aging process, loneliness, cognitive and psychomotor impairment, reduced physical attractiveness, etc. These factors often discourage individuals, and they subsequently avoid having to confront their deteriorating psychosexual performance.

Social attitudes toward all forms of sexual activity among older people are negative and harsh. Many people associate sex with procreation; however, since the elderly cannot procreate, people believe that their sexual activity should be reduced to a minimum if not completely cease. People also argue that the elderly should not engage in sexual activity for aesthetic, health, moral, and other reasons. Consequently, this weakens the elderly's readiness to express intimacy and reduces their libido. However, if the elderly do seek to fulfill their need for sex, then they may do so with a sense of guilt, sinfulness, immorality, and fear of not following sexual norms, which, in turn, can lead to a reduction in satisfaction, interpersonal conflicts, etc.

\section{A Psychoanalytic Approach to the Problem of Old Age}

During its early stages of the development, psychoanalysis was reluctant and skeptical about therapeutically treating old age. Freud noted in his work that, since the elderly's mental processes are less flexible and since the length of therapy is limited, the elderly would not experience the psychotherapeutic effects of psychoanalysis. ${ }^{6}$ Freud's position,

\footnotetext{
$5 \quad$ I. Stankowska, "Funkcjonowanie seksualne człowieka w okresie starzenia się i starości," Przegląd Terapeutyczny, no. 4 (2008).
}

$6 \quad$ A, Przewłocka-Alves, "Psychologia starości." 
however, was significantly challenged when new and varied aims of psychoanalytic therapies were introduced. Although the possibility to thoroughly reconstruct the personality is significantly reduced during old age, there are many psychic areas that can be analyzed and treated effectively. The psychodynamic approach to personal development, the way of thinking based on insight, and the therapeutic bond give individuals the opportunity to rebuild trust in themselves and increase their creativity and dynamism. During therapy with the elderly, it is possible to focus on the immediate aspects of the way that they function, work toward achieving a balance in life, set immediate goals, and focus on the most troubling and current mental and relationship problems. Although the length of psychotherapy is limited, age does not have to be a contraindication to initiate psychodynamic-oriented therapeutic work.

During old age, the possibility of thoroughly reconstructing the personality is probably significantly reduced, but there are many psychic areas that can be effectively worked on and analyzed. The psychodynamic approach to personal development, thinking based on insight, and the relationship between a therapist and patient give the elderly chance to rebuild their self-confidence and increase their dynamism and creativity. During psychotherapy with the elderly, therapists can focus on the immediate aspects of the elderly's functioning, help them achieve a balance in life, set goals, and address their most difficult and current mental and relational problems. In this way, the time-constraint of therapy and the advanced age of the elderly do not have to be contraindications to beginning psychodynamically-oriented therapeutic work.

Ferenczi emphasized that, during old age, a person focuses his energy mainly on strengthening his narcissism. ${ }^{7}$ As a result, an individual may concentrate on himself and his health, which leads to the impoverishment of his social relationships. In turn, this can increase a person's social isolation, his hypersensitive reactions, and his tendency to treat his partner as an extension of his own narcissism. Karl Abraham, however, believed that there was no need for such rigid standards and assumptions regarding psychodynamic therapy for the elderly, meaning that therapy is possible for people of all ages, and that it can produce the desired results. ${ }^{8}$

Peter L. Rudnytsky, Ferenczi's Turn in Psychoanalysis (New York: New York University Press, 2000).

$8 \quad$ K. Abraham, Oeuvres comple`tes, Vol. 2. (Paris: 1965), in A. Przewłocka-Alves, "Psychologia starości." 
Psychoanalysis emphasizes that the ego is quite weak during old age because it must experience many inter- and intrapsychological losses. In this situation, the ego is devoid of libidinal energy. During old age, the ego must also deal with what it was before and how it functioned, and it must become accustomed to new and different conditions. When considering analytical topographical theory, it is possible to assert that the death drive dominates during old age; as a consequence, the superego may become more or less rigid, or it might become weakened by consciousness of impending death. Therefore, sometimes the elderly may manifest impulsive, risky, and borderline behaviors, and, on the other hand, an increase in normative, punitive, and restrictive thoughts and behaviors that disable spontaneity and reinforce masochistic tendencies.

In the $1980 \mathrm{~s}$, Henri Bianchi described aging as a process that resembles mourning the loss of the ego, since older people have to mourn the loss of their narcissism. ${ }^{9}$ The psychological work of aging is adapting the ego to changes in the body. Often the psyche is fixated on some stage of life, but through the aging process the body forces the psyche to confront the fact that time is passing, aging is inevitable, and death will come. The therapeutic work of old age is, therefore, to help the ego pass through this trial and adapt to ongoing physical changes.

\section{A Behavioral-Cognitive Approach to the Problem of Old Age}

This article approaches the problem of old age with the assumption that thoughts, emotions, and behaviors influence each other. The goal of this article is to change people's convictions and behaviors. ${ }^{10}$ Thoughts influence emotions and behaviors, but they also depend on individuals' current moods and the consequences of their past actions. The way in which individuals interpret events influences how they behave. If distorted, a person's beliefs, (lack of) ability to process information, and cognitive deficits can lead to emotional and behavioral disorders. ${ }^{11}$ In 1962, Ellis explained the mechanisms of psychiatric disorders using the following ABC Model: Activating Event - Beliefs Consequences. In the case of this article, the activating event is old age, which entails experiences of loss and the gradual reduction of one's

\footnotetext{
$9 \quad$ A. Przewłocka-Alves, "Psychologia starości."

10 A. Bandura, Teoria społecznego uczenia się (Wydawnictwo Naukowe PWN, 2007).

11 A. Ellis, Reason and Emotion in Psychotherapy (New York: Stuart, 1962).
} 
abilities in many areas of life. There are not yet elements of the aging process that produce specific predictable reactions and outcomes. Only when individuals interpret the experiences of old age that give their life value and meaning will they be able to respond emotionally. For example, one person might treat old age as the next developmental phase of his life that presents new opportunities and challenges to grow spiritually, psychologically, mentally, and physically. Having more time to do so, this person can afford to take a deeper look at himself and his needs. Such an attitude will lead to internal harmony and the satisfaction of being involved in something that, in turn, will help him use his psychic resources. On the other hand, another person undergoing the aging process might interpret old age to mean that things are no longer possible. This, in turn, evokes negative emotions. In this sense, disorders of functioning during old age are a consequence of dysfunctional assumptions, beliefs, and automatic thoughts that demoralize an individual, take away his motivation, and increase his resignation. These kinds of dysfunctional beliefs are manifested in an "either all or nothing" attitude, generalization of negative events, automatic depreciation of positive news, exaggerating imperfections, and diminishing positive qualities, referring everything to one's self and seeing one's self as the center of the world, and thoughts dominated by orders and prohibitions. In behavioral-cognitive therapy, the method of identifying dysfunctional beliefs and inappropriate attitudes towards old age is so-called "cognitive restructuring," the goal of which is to eliminate dysfunctional beliefs and introduce new ones that do not have negative effects. Since that which people believe has an impact on how they behave, changes in belief can evoke changes in behavior.

\section{PSYCHOLOGICZNE TRUDNOŚCI W ADAPTACJI DO PROCESU STARZENIA SIĘ U CZŁOWIEKA}

W pierwszej części artykułu omówione zostaną prawidłowości procesu starzenia się u człowieka. Następnie analizowane będą różnorodne zmienne psychologiczne mogące mieć wpływ na zakłócenia w tym procesie, takie jak: zmienne osobowościowe, obraz ciała, spełnienie w roli osobistej i zawodowej, satysfakcja z relacji partnerskiej, samoocena, akceptacja procesu przemijania i zmian temu towarzyszących i wiele innych. W osobnym punkcie omówione zostaną zagadnienia życia intymnego w wieku starczym jako istotnym elemencie mogącym mieć znaczący wpływ na przebieg procesu adaptacji do procesu starzenia. Całość zaprezentowana zostanie z perspektywy psychodynamicznej, 
bazującej na obserwacjach klinicznych autora tego doniesienia, który praktykuje w tym nurcie od wielu lat. Poruszane będą m.in. takie kwestie jak: rozwiązywanie podstawowych konfliktów intrapsychicznych, umiejętność czerpania z wewnętrznej siły i odwoływanie się do części konstruktywnej w sobie, przeżycie żałoby po różnego typu utratach, budowanie adekwatnego obrazu siebie w stosunku do idealistycznego wyobrażenia, uzyskanie wewnętrznej harmonii itp. Zaprezentowane zostaną też podstawowe odniesienia do tematu w ujęciu poznawczym.

Słowa kluczowe: starość, psychoanaliza, terapia behawioralno-poznawcza, zmienne osobowościowe.

\section{Bibliography:}

1. Abraham, K. Oeuvres comple ‘es, Vol. 2. Paris: 1965. In A. PrzewłockaAlves. "Psychologia starości w ujęciu psychoanalitycznym i perspektywy psychoterapeutycznej." Theologica Wratislaviensia 10 (2015).

2. Bandura, A. Teoria spotecznego uczenia się. Wydawnictwo Naukowe PWN, 2007.

3. Ellis, A. Reason and Emotion in Psychotherapy. New York: Stuart, 1962.

4. Havighurst, R. J. "Zadania rozwojowe kolejnych okresów życia i warunki wypełniania." Encyklopedia Pedagogiczna. Warsaw: Fundacja Innowacja, 1997, 952-953.

5. Nowicka, A. Wybrane problemy osób starszych. Oficyna Wydawnicza Impuls, 2010

6. Przewłocka-Alves, A. "Psychologia starości w ujęciu psychoanalitycznym i perspektywy psychoterapeutycznej." Theologica Wratislaviensia 10 (2015).

7. Rudnytsky, Peter L. Ferenczi's Turn in Psychoanalysis. New York: New York University Press, 2000.

8. Stankowska, I. "Funkcjonowanie seksualne człowieka w okresie starzenia się i starości." Przeglad Terapeutyczny, no. 4 (2008).

9. Zawadzka, D., and M. Stalmach. "Problemy psychologiczne osób w okresie starości. Cz. I. Najważniejsze wyzwania i trudności." Hygeia Public Health 2 , no. 50 (2015): 298-304. 